\title{
Cranial diabetes insipidus caused by giant cell arteritis
}

\author{
Macherla Radhamanohar
}

St Ann's Hospital, Tottenham, London N15 3TH, UK.

\begin{abstract}
Summary: A 78 year old woman was admitted with symptoms of diabetes insipidus and was found to have a high ESR, the cause of which was uncertain.

Five months later she presented with blindness, and cranial arteritis was confirmed by temporal artery biopsy. The endocrine abnormality returned to normal after steroid therapy. The association between these two conditions is discussed.
\end{abstract}

\section{Introduction}

Giant cell arteritis is known to affect various intracranial and extracranial arteries. It usually presents with headaches, weight loss and visual symptoms, and other complications may be revealed later during its course. Intra-cranial involvement is infrequent and endocrine abnormality as a complication is rare. I present a case of giant cell arteritis presenting with diabetes insipidus. To my knowledge, this association has not been previously reported.

\section{Case report}

A 78 year old woman was admitted in February, 1986 with 2 months' history of excessive thirst, polydipsia, polyuria and weight loss. She had no headaches, visual symptoms, myalgia or muscular weakness, and was not on any medication.

Her blood pressure was $150 / 85 \mathrm{mmHg}$. Systemic examination revealed no muscular tenderness or weakness. Temporal arteries were pulsatile and non-tender. Apart from arterial narrowing, the optic fundi were normal. No visual field defects were noted. Haemoglobin was $10.8 \mathrm{~g} / \mathrm{dl}$ with a normocytic and normochromic picture. ESR was $112 \mathrm{~mm} / \mathrm{h}$. Blood urea was $3.8 \mathrm{mmol} / \mathrm{l}$, blood glucose $5.7 \mathrm{mmol} / \mathrm{l}$, serum calcium $2.21 \mathrm{mmol} / 1$ and albumin $31 \mathrm{~g} / \mathrm{l}$. Serum sodium was $139 \mathrm{mmol} / \mathrm{l}$, serum potassium $4.4 \mathrm{mmol} / \mathrm{l}$. Serum thyroxine, prolactin and DNA antibody level, and chest X-ray were all normal.

The urine output varied from 4.8 to 5 litres $/ 24 \mathrm{~h}$.

Correspondence: M. Radhamanohar, M.R.C.P., M.D., 8 Carfax Road, Elm Park, Hornchurch, Essex RM12 4BA, UK.

Accepted: 7 June 1988
Urine osmolality was $120-135 \mathrm{mosmol} / \mathrm{kg}$ and serum osmolality $282 \mathrm{mosmol} / \mathrm{kg}$. After 8 hours' water deprivation serum osmolality was $283 \mathrm{mosmol} / \mathrm{kg}$ and urine osmolality $132 \mathrm{mosmol} /$ $\mathrm{kg}$. After a desmopressin injection it rose to $414 \mathrm{mosmol} / \mathrm{kg}$. Computerized tomography of the head showed minor cerebral atrophy but no pituitary or hypothalamic lesion.

A diagnosis of cranial diabetes insipidus was made and therapy with desmopressin was commenced, initially $10 \mu \mathrm{g}$ twice daily intranasally. Symptoms dramatically improved and urine osmolality increased to $660-810 \mathrm{mosmol} / \mathrm{kg}$. The ESR remained at $112 \mathrm{~mm} / \mathrm{h}$ when she was discharged in May, 1986 on desmopressin $15 \mu \mathrm{g}$ twice daily.

In July 1986 she complained of severe deterioration in vision for 2 weeks. She had no headaches or neuromuscular symptoms. The blood pressure was unchanged. The temporal arteries were still pulsatile and non-tender. She could count fingers at 1 yard with the right eye but with the left, only perception of light was possible. No visual field defects were noted. The optic discs were pale and swollen with haemorrhages near the discs in both the eyes. The ESR remained at $100 \mathrm{~mm} / \mathrm{h}$, and cranial computerized tomogram was similar to the previous one. Temporal arteritis was diagnosed and confirmed by temporal artery biopsy which showed focal infiltration by lymphocytes and histiocytes with degeneration . of the elastica. Prednisolone $60 \mathrm{mg} /$ day was commenced and later was gradually reduced. Vision markedly improved and the ESR dropped to $12 \mathrm{~mm} / \mathrm{h}$ over the following few weeks.

In December 1986 the water deprivation test was repeated. Desmopressin was discontinued 20 days before the test. Urine osmolality was $200 \mathrm{mosmol} /$

(C) The Fellowship of Postgraduate Medicine, 1988 
$\mathrm{kg}$ before, $732 \mathrm{mosmol} / \mathrm{kg}$ (with serum osmolality $301 \mathrm{mosmol} / \mathrm{kg}$ ) after 8 hours' water deprivation and $850 \mathrm{mosmol} / \mathrm{kg}$ after pitressin tannate injection.

She has been followed up and has had no recurrence of symptoms related to diabetes insipidus but still has some residual defect of visual acuity. The random urinary osmolality was $431 \mathrm{mosmol} / \mathrm{kg}$ in early 1987 without desmopressin therapy.

\section{Discussion}

After 8 hours' strict water deprivation the patient became confused and agitated. Though there was only marginal increase in plasma osmolality the test could not be prolonged because of her poor clinical state. However, the dilute urine after water deprivation with a marked [threefold] increase in urine osmolality after desmopressin and the dramatic improvement in her symptoms and urinary concentration on desmopressin therapy confirmed the diagnosis of cranial diabetes insipidus. Clinical findings and investigations in this case did not suggest any known causes of diabetes insipidus such as granulomas, neoplasia, or cerebral haemorrhage involving hypothalamic-pituitary area. Reversal of urinary concentration to normal, while she was off desmopressin therapy could have been due to improvement in the underlying pathology following steroid therapy. Therefore it is most likely that diabetes insipidus in this case was caused by giant cell arteritis of the vessels supplying the hypothalamic hypopituitary area.

Giant cell arteritis infrequently involves various intracranial arteries. Caselli et al. ${ }^{1}$ discussed the neurological problems caused by the involvement of intracranial arteries in biopsy-proven giant cell arteritis. Transient ischaemic attacks and strokes were reported in $7 \%$ of cases and neuroophthalmological problems in $21 \%$ of the patients with biopsy-proven giant cell arteritis. Tang and Hollenhorst $^{2,3}$ separately discussed different ophthalmoscopic findings in giant cell arteritis and the funduscopic findings in this case fit in with changes caused by ischaemic optic neuropathy. Hollenhorst et al. ${ }^{3}$ noted one case of temporal arteritis with pituitary cyst but the effect of this lesion on endocrine function was not described. Everett et $a l^{4}$ reported one case of hypothalamichypopituitarism developed during the active phase of temporal arteritis. Small pituitary infarcts were noted in necropsy findings of a case with giant cell arteritis reported by Gilmour, ${ }^{5}$ but no functional endocrine abnormality was described. Cerebral haemorrhage, thrombosis and Sheehan's syndrome are among the known vascular causes of cranial diabetes insipidus. Recently diabetes insipidus following severe gastrointestinal bleeding has been described. ${ }^{6}$ Very few cases of cranial diabetes insipidus in association with vasculitis have been reported in the past. Balkin et al. ${ }^{7}$ described a case of severe rheumatoid arthritis who developed diabetes insipidus during the phase of active vasculitis. About five cases of cranial diabetes insipidus have so far been documented by different authors as a complication of Wegener's granulomatosis. ${ }^{8,9}$ Local vasculitis or granulomatosis of hypothalamicpituitary area was thought to be responsible in these cases. Some of these cases have responded to the treatment of Wegener's granulomatosis with cyclophosphamide. To my knowledge no case of cranial diabetes insipidus due to giant cell arteritis has so far been documented.

\section{Comment}

This case of temporal arteritis is of interest in its association and presentation with diabetes insipidus. It also shows that endocrine dysfunction may be transient and may improve by treating the underlying pathology, giant cell arteritis. It emphasizes the importance that physicians should be aware of the possibility of pituitary dysfunction among other intracranial involvements in giant cell arteritis.

\section{Acknowledgements}

I wish to thank $\mathrm{Dr}$ W. Woothipoom, Consultant Physician in Medicine for the Elderly, for his critical comments and Dr P. Ranmuthu, Consultant Physician in Medicine for the Elderly for his helpful suggestions.

\section{References}

1. Caselli, R.J., Hunder, G.G. \& Whisnant, J.P. Neurological disease in biopsy-proven giant cell [temporal] arteritis. Neurology 1988, 38: 352-359.

2. Tang, R.A. \& Kaldis, L.C. Retinopathy in temporal arteritis. Ann Ophthalmol 1982, 16: 652-654.

3. Hollenhorst, R.W., Brown, J.R., Wagener, H.P. \& Schick, R.M. Neurological aspects of temporal arteritis. Neurology 1960, 10: 490-498. 
4. Everett, G.D., Amatruda, J.M. \& Woolf, P.D. Hypothalamic-hypopituitarism due to temporal arteritis. Arch Intern Med 1979, 139: 474-475.

5. Gilmour, J.R. Giant cell chronic arteritis. J Pathol Bacteriol 1941, 53: 263-277.

6. Wickramasinghe, L.S.P., Chazan, B.I. \& Mandall, A.R. Cranial diabetes insipidus after upper gastrointestinal haemorrhage. $\mathrm{Br}$ Med $J$ 1988, 296: 969.

7. Balkin, M., Repice, M., Dua, N. \& Kleinman, L. Acute onset of diabetes insipidus in a patient with an active vasculitis. $N Y$ State J Med 1986, 86: 538-539.
8. Hurst, N.P., Dunn, N.A. \& Chalmers, T.M. Wegener's granulomatosis complicated by diabetes insipidus. Ann Rheum Dis 1983, 42: 600-601.

9. Goebel, Von R., Jakse, R., Passath, A. \& Michlmayr, G. Wegener's granulomatosis causing diabetes insipidus. Fortschr Med 1982, 100: 1400-1401. 